\title{
Front Matter: Volume 7891
}

, "Front Matter: Volume 7891," Proc. SPIE 7891, Design and Quality for Biomedical Technologies IV, 789101 (22 March 2011); doi: 10.1117/12.891037

SPIE. Event: SPIE BiOS, 2011, San Francisco, California, United States 


\title{
PROGRESS IN BIOMEDICAL OPTICS AND IMAGING
}

Vol. 12, No. 9

\section{Design and Quality for Biomedical Technologies IV}

\author{
Ramesh Raghavachari \\ Rongguang Liang \\ Editors
}

23-25 January 2011

San Francisco, California, United States

Sponsored and Published by

SPIE

Volume 7891

Proceedings of SPIE, 1605-7422, v. 7891

SPIE is an international society advancing an interdisciplinary approach to the science and application of light. 
The papers included in this volume were part of the technical conference cited on the cover and title page. Papers were selected and subject to review by the editors and conference program committee. Some conference presentations may not be available for publication. The papers published in these proceedings reflect the work and thoughts of the authors and are published herein as submitted. The publisher is not responsible for the validity of the information or for any outcomes resulting from reliance thereon.

Please use the following format to cite material from this book:

Author(s), "Title of Paper," in Design and Quality for Biomedical Technologies IV, edited by Ramesh Raghavachari, Rongguang Liang, Proceedings of SPIE Vol. 7891 (SPIE, Bellingham, WA, 2011) Article CID Number.

ISSN 1605-7422

ISBN 9780819484284

Published by

SPIE

P.O. Box 10, Bellingham, Washington 98227-0010 USA

Telephone +1 3606763290 (Pacific Time) · Fax +1 3606471445

SPIE.org

Copyright (C) 2011, Society of Photo-Optical Instrumentation Engineers.

Copying of material in this book for internal or personal use, or for the internal or personal use of specific clients, beyond the fair use provisions granted by the U.S. Copyright Law is authorized by SPIE subject to payment of copying fees. The Transactional Reporting Service base fee for this volume is $\$ 18.00$ per article (or portion thereof), which should be paid directly to the Copyright Clearance Center (CCC), 222 Rosewood Drive, Danvers, MA 01923. Payment may also be made electronically through CCC Online at copyright.com. Other copying for republication, resale, advertising or promotion, or any form of systematic or multiple reproduction of any material in this book is prohibited except with permission in writing from the publisher. The CCC fee code is 1605$7422 / 11 / \$ 18.00$.

Printed in the United States of America.

Publication of record for individual papers is online in the SPIE Digital Library.

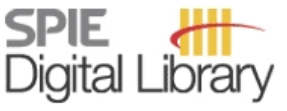

SPIEDigitallibrary.org

Paper Numbering: Proceedings of SPIE follow an e-First publication model, with papers published first online and then in print and on CD-ROM. Papers are published as they are submitted and meet publication criteria. A unique, consistent, permanent citation identifier (CID) number is assigned to each article at the time of the first publication. Utilization of CIDs allows articles to be fully citable as soon as they are published online, and connects the same identifier to all online, print, and electronic versions of the publication. SPIE uses a six-digit CID article numbering system in which:

- The first four digits correspond to the SPIE volume number.

- The last two digits indicate publication order within the volume using a Base 36 numbering system employing both numerals and letters. These two-number sets start with 00, 01, 02, 03, 04, $05,06,07,08,09,0 A, 0 B \ldots 0 Z$, followed by 10-1Z, 20-2Z, etc.

The CID number appears on each page of the manuscript. The complete citation is used on the first page, and an abbreviated version on subsequent pages. Numbers in the index correspond to the last two digits of the six-digit CID number. 


\section{Contents}

vii Conference Committee

\section{QUALITY OF BIOMEDICAL TECHNOLOGIES I}

789103 Improving patient and user safety during endoscopic investigation of the pancreatic and biliary ducts [7891-03]

J. E. Chandler, C. D. Melville, C. M. Lee, Univ. of Washington (United States); M. D. Saunders, Univ. of Washington Medical Ctr. (United States); M. R. Burkhardt, E. J. Seibel, Univ. of Washington (United States)

789104 Reduction of noise floor for molecular, fluorescence-enhanced optical imaging [7891-04] B. Zhu, J. C. Rasmussen, Y. Lu, E. M. Sevick-Muraca, The Univ. of Texas Health Science Ctr. at Houston (United States)

\section{CALIBRATION OF IMAGING TECHNOLOGIES}

7891 OA Calibration schemes of a field-compatible optical spectroscopic system to quantify neovascular changes in the dysplastic cervix [7891-09]

V. T.-C. Chang, Duke Univ. (United States); D. Merisier, Family Health Ministries (Haiti); B. Yu, Duke Univ. (United States); D. K. Walmer, Family Health Ministries (Haiti) and Duke Univ. Medical Ctr. (United States); N. Ramanujam, Duke Univ. (United States)

\section{NOVEL IMAGING TECHNOLOGIES}

7891 OC Spectrum resolved fluorescence imaging in multi-focal volume holographic microscopy (Invited Paper) [7891-11]

Y. Luo, I. Zervantonakis, S. B. Oh, R. Kamm, G. Barbastathis, Massachusetts Institute of Technology (United States)

7891 OD Laser Doppler blood flow imaging with a $64 \times 64$ pixel full custom CMOS sensor [7891-12] D. He, H. C. Nguyen, B. R. Hayes-Gill, Y. Zhu, J. A. Crowe, S. P. Morgan, The Univ. of Nottingham (United Kingdom); G. F. Clough, C. A. Gill, Univ. of Southampton School of Medicine (United Kingdom)

7891 OE Detection of physiological changes after exercise via a remote optophysiological imaging system [7891-13]

Y. Sun, Loughborough Univ. (United Kingdom) and Shanghai Jiao Tong Univ. (China); S. Hu, V. Azorin-Peris, J. Zheng, Loughborough Univ. (United Kingdom); S. Greenwald, Barts and The London School of Medicine and Dentistry (United Kingdom); J. Chambers, Loughborough Univ. (United Kingdom); Y. Zhu, Shanghai Jiao Tong Univ. (China) 
7891 OF Broadband UV-Vis optical property measurement in layered turbid media [7891-14] Q. Wang, U.S. Food and Drug Administration (United States); D. Le, J. Ramella-Roman, The Catholic Univ. of America (United States); J. Pfefer, U.S. Food and Drug Administration (United States)

7891 OG Pseudo-random single photon counting system: a high speed implementation and its applications [7891-15]

Q. Zhang, N. Chen, National Univ. of Singapore (Singapore)

DESIGN OF BIOMEDICAL IMAGING DEVICES AND TECHNOLOGIES

$7891 \mathrm{OH} \quad$ Multiphoton imaging for deep tissue penetration and clinical endoscopy (Invited Paper) [7891-16]

C. Xu, Cornell Univ. (United States)

\section{OCT AND POLARIZATION IMAGING TECHNIQUES}

7891 OM Optical coherence tomography using bessel beams (Invited Paper) [7891-34]

K.-S. Lee, S. Vo, J. P. Rolland, The Institute of Optics, Univ. of Rochester (United States)

789100 Micron-class axial resolution FD OCT with high acquisition speed using a broadband astigmatism-corrected spectrometer [7891-22]

K.-S. Lee, S. K. Mahalik, K. P. Thompson, J. P. Rolland, The Institute of Optics, Univ. of Rochester (United States)

7891 OP Phase-resolved Doppler imaging with dual-detection full-range frequency domain optical coherence tomography [7891-23]

P. Meemon, K. S. Lee, J. P. Rolland, The Institute of Optics, Univ. of Rochester (United States)

$78910 Q \quad$ Compact polarization diverse receiver for biomedical imaging applications [7891-24]

D. Neill, L. Stewart, Finisar Australia Pty. Ltd. (Australia); H. Li, Finisar Shanghai, Inc. (China);

T. Killin, Finisar Australia Pty. Ltd. (Australia); F. Chen, Finisar Shanghai, Inc. (China); S. Frisken,

G. Baxter, S. Poole, Finisar Australia Pty. Ltd. (Australia)

7891 OR Polarimetric scattering signature imaging of highly photon-scattering bio-medium [7891-25] S. H. Wu, P.-H. Chen, National Yang-Ming Univ. (Taiwan); D.-M. Yang, Taipei Veterans General Hospital (Taiwan); H.-W. Wang, A. Chiou, National Yang-Ming Univ. (Taiwan); S.-M. F. Nee, Neopola Optical Analysis Inc. (United States); T.-W. Nee, National Yang-Ming Univ. (Taiwan)

\section{HYPERSPECTRAL IMAGING SYSTEMS}

7891 OS Correction of axial optical aberrations in hyperspectral imaging systems [7891-26]

Ž. Špiclin, Univ. of Ljubljana (Slovenia); F. Pernuš, B. Likar, Univ. of Ljubljana (Slovenia) and Sensum Computer Vision Systems (Slovenia)

7891 OT Illumination system characterization for hyperspectral imaging [7891-27]

J. Katrašnik, Univ. of Ljubljana (Slovenia); F. Pernuš, B. Likar, Univ. of Ljubljana (Slovenia),

Sensum Computer Vision Systems (Slovenia) 
7891 OV Low-light hyperspectral imager for characterization of biological samples based on an sCMOS image sensor [7891-29]

J. Hernandez-Palacios, Norwegian Defense Research Establishment (Norway), Norsk Elektro Optikk AS (Norway), and Univ. of Oslo (Norway); L. L. Randeberg, I. J. Haug, Norwegian Univ. of Science and Technology (Norway); I. Baarstad, T. Løke, Norsk Elektro Optikk AS (Norway); T. Skauli, Norwegian Defense Research Establishment (Norway)

7891 OW Characterization of hyperspectral imaging and analysis via microarray printing of dyes [7891-30]

M. L. Clarke, M. Litorja, D. W. Allen, D. V. Samarov, J. Hwang, National Institute of Standards and Technology (United States)

\section{POSTER SESSION}

7891 OY

Calibration methods of near-infrared frequency domain diffused light measurement system [7891-32]

Y. Fan, H. Zhao, X. Zhou, J. Liang, T. Wang, F. Gao, Tianjin Univ. (China)

$78910 Z$ Real-time fluorescence polarization microscopy for probing local distributions of biomolecules [7891-33]

J. Y. Lee, National Institute of Standards and Technology (United States) and National Institutes of Health (United States); J. F. Lesoine, National Institutes of Health (United States); J. R. Krogmeier, National Institute of Standards and Technology (United States) and Life Technologies, Inc. (United States); H. Kang, M. Clarke, R. Chang, National Institute of Standards and Technology (United States); D. L. Sackett, R. Nossal, National Institutes of Health (United States); J. Hwang, National Institute of Standards and Technology (United States)

Author Index 
Downloaded From: https://www.spiedigitallibrary.org/conference-proceedings-of-spie on 26 Apr 2023

Terms of Use: https://www.spiedigitallibrary.org/terms-of-use 


\title{
Conference Committee
}

\author{
Symposium Chairs
}

James G. Fujimoto, Massachusetts Institute of Technology (United States)

R. Rox Anderson, Wellman Center for Photomedicine, Massachusetts General Hospital (United States) and Harvard School of Medicine (United States)

Program Track Chairs

Tuan Vo-Dinh, Duke University (United States)

Anita Mahadevan-Jansen, Vanderbilt University (United States)

Conference Chairs

Ramesh Raghavachari, U.S. Food and Drug Administration (United States)

Rongguang Liang, Carestream Health, Inc. (United States)

Conference Cochair

Joshua Pfefer, U.S. Food and Drug Administration (United States)

Program Committee

Anthony J. Durkin, Beckman Laser Institute and Medical Clinic (United States)

Kazuhiro Gono, Olympus Medical Systems Corporation (Japan)

Jeeseong Hwang, National Institute of Standards and Technology (United States)

Stephen P. Morgan, The University of Nottingham (United Kingdom)

Jannick P. Rolland-Thompson, The Institute of Optics, University of Rochester (United States)

Eric J. Seibel, University of Washington (United States)

Tomasz S. Tkaczyk, Rice University (United States)

Rudolf $\mathbf{M}$. Verdaasdonk, Vrije University Medical Center (Netherlands)

Session Chairs

Quality of Biomedical Technologies I

Joshua Pfefer, U.S. Food and Drug Administration (United States) 
Keynote Presentation

Ramesh Raghavachari, U.S. Food and Drug Administration (United States)

Calibration of Imaging Technologies

Anthony J. Durkin, Beckman Laser Institute and Medical Clinic (United States)

Eric J. Seibel, University of Washington (United States)

Novel Imaging Technologies

Ramesh Raghavachari, U.S. Food and Drug Administration (United States)

Design of Biomedical Imaging Devices and Technologies

Rongguang Liang, Carestream Health, Inc. (United States)

OCT and Polarization Imaging Techniques

Stephen P. Morgan, The University of Nottingham (United Kingdom)

Hyperspectral Imaging Systems

Jeeseong Hwang, National Institute of Standards and Technology (United States) 